\title{
Diyetten Alınan ve Kandaki Demir Mineralinin İnsan İnce Bağırsak Hücre Modelinde Demir Eksikliği Anemisine Etkisi
}

\author{
The Effect of Diet and Blood Derived Iron on Iron Deficiency Anemia in the Model of Human \\ Intestine
}

\section{Şükrü Güleç}

Geliş tarihi/Received: 13.04.2018 • Kabul tarihi/Accepted: 17.08.2018

\section{ÖZET}

Amaç: Demir eksikliğine bağlı anemi (IDA), dünyada özellikle yeni doğanlarda, çocuklarda ve kadınlarda en sık görülen besinsel eksikliktir. Düşük demir içeriği olan besinlerin tüketilmesi ve ince bağırsaktan yeterli demirin emilememesi demir eksikliğine bağlı anemiye neden olmaktadır. Memelilerde fizyolojik olarak aktif demirin vücuttan atılımı için bir sistemin olmamasından dolayı bağırsak enterosit hücreleri, vücuttaki demir metabolizmasının dengeli bir şekilde devamlılı̆̆ında hayati bir role sahiptirler. Yeterli bağırsak demir emilimi anemi riskini azaltmak için gereklidir. Diyetten alınan ve kanda bulunan demir insan vücudu için bulunan iki demir kaynağıdır. Bu çalışmada demir eksikliğine bağlı anemi durumunda bağırsak demir metabolizmasının moleküler ve genetik düzenlenmesinde diyetten gelen ve kanda bulunan demir mineralinin etkisinin incelenmesi amaçlanmıştır.

Gereç ve Yöntem: İnsan kolon epitelyal hücreleri (CaCo-2) insan ince bağırsak sistemini modellemek için özel hücre kültürü membran sistemlerinde büyütülmüştür. Kolon hücrelerin apikal ve bazolateral polarizasyonu trans epitelyal rezistans (TEER) ölçümüyle test edilmiştir. Demir eksikliğine bağlı anemi Deferoxamine (DFO) ile indüklenmiş olup, demirin IDA üzerindeki etkisi RT-qPCR tekniği ile gen düzeyinde araştırılmıştır.

Bulgular: Marker gen (TFR, DMT1) mRNA ekspresyon düzeyleri analiz edildiğinde, hücrelerin bazolateral kısmına demir verildiğinde apikal kısma verilene oranla IDA fenotipinin kaybolduğu gösterilmiştir.

Sonuç: Sonuçlar kan demirinin bağırsak demir metabolizmasının düzenlenmesi için gerekli olduğunu göstermiştir. Kan demir düzeyi diyetten gelen demirle regüle edilir. Böylece, günlük demir alımı kan demiri düzeylerini düzenlemek için önemlidir. Bağırsak enterosit hücrelerinin bazolateral kısım boyunca demir mineralini algılama kabiliyetine sahip olabileceğini desteklemektedir.

Anahtar kelimeler: Demir eksikliği anemisi, CaCo-2 hücre hattı, enterosit hücreleri, gen regülasyonu

\section{ABSTRACT}

Aim: Iron deficiency anemia (IDA) is the most common global nutritional deficiency especially in women, children and infants. Consumption of low dietary iron and inadequate intestinal iron intake cause IDA. Intestine of enterocyte cells play a vital role to maintain body iron homeostasis since mammals do not have active physiological iron excretion mechanism. Efficient intestinal iron absorption is essential to decrease risk of anemia. Diet and blood derived iron are two source for human body. Thus, the aim of this study was to investigate the effects of dietary and blood iron minerals on the molecular and genetic regulation of intestinal iron metabolism during IDA.

1. İletişim/Correspondence: İzmir Yüksek Teknoloji Enstitüsü Gıda Mühendisliği Bölümü, Oda no:215, 35430 Urla, İzmir, Türkiye • E-posta: sukrugulec@iyte.edu.tr 
Material and Method: The human colon epithelial cells (Caco-2 cells) were grown on special bicameral cell culture insert systems to mimic the human small intestine. The apical and basolateral polarization of the cells were tested by trans epithelial electrical resistance (TEER) measurement. IDA was induced by Deferoxamine (DFO) and the effect of iron on IDA was investigated at the gene regulation levels by RT-qPCR technique.

Results: Our main result showed that when iron was given into basolateral side of cells, iron deficient phenotype was disappeared compared to apical side iron treatment by analyzing mRNA expression levels of marker genes (TFR and DMT1).

Conclusion: This study suggests that blood iron is essential to maintain intestinal iron metabolism. The blood iron level is regulated through dietary iron. Therefore, daily iron intake is important to maintain blood iron levels. Moreover, our results also suggest that enterocyte cells might have ability to sense iron mineral through basolateral side.

Keywords: Iron deficiency anemia, Caco-2 Cells, enterocyte cells, gene regulation

\section{GİRIŞ}

Demir eksikliği vücuttaki demir depolarının yeterli olmaması ve besinlerden alınan demir miktarının düşük olması ile ortaya çıkabilmektedir $(1,2)$. Dünyada besin eksikliğinden kaynaklanan metabolik sorunların başında demir eksikliğine bağlı anemi gelmektedir (3). Bunun yanında menstrual kanamalar, yaralanmalar, gizli kan kayıpları birincil dereceden demir eksikliği riski oluştururken, gebelik, doğum sonrası emzirme dönemlerindeki fizyolojik değişikliklere bağlı olarak da vücudun demir ihtiyacı artmaktadır (3). Dünya genelinde hamile kadınların $\% 40$ 'ında ve okul öncesi dönemdeki çocukların \%47’sinde anemi görülürken, Dünya Sağllk Örgütü (DSÖ) dünya genelinde görülen aneminin en az \%50'sinin demir eksikliğine bağlı olduğunu belirtmiştir (4). Türkiye'de ise demir eksiliğine bağlı anemi görülme oranı yaş gruplarına göre \%30-50 arasında değişmektedir (5). Bu veriler besinlerden alınabilecek demirin sağlık açısından önemini ortaya koymaktadır. Demir minerali hücrelere oksijen taşınmasında, enerji metabolizmasında, hücre bölünmesinde, canlı gelişiminde, vücut savunma sistemi gibi insan için önemli birçok fizyolojik olayda görev yapmaktadır (6).

Kimyasal özelliğinden dolayı demir mineralinin vücuttaki miktarı çok önemlidir. Eksikliği anemiye neden olurken, fazlalığında ise toksik etki görülmektedir (7). Bu yüzden vücut içerisindeki demir miktarının en uygun düzeyde olması çok önemlidir.
Memelilerde demirin vücut dışına atılması adına özelleşmiş aktif bir fizyolojik sistem bulunmamaktadır (8). Vücuttaki demir miktarının kontrolü, besinlerden gelen demirin emildiği ince bağırsak enterosit hücreleri tarafından sağlanmaktadır (8). Bu yüzden demir metabolizmasının moleküler düzeyde kontrolü çok önemlidir. Demir minerali besinlerde iyonik olarak serbest veya hem grubuna bağlı olarak bulunmaktadır. Bağırsaktaki besin emiliminden sorumlu enterosit hücrelerinde emilen bu iki farklı demir formu hücre içerisine girdikten sonra aynı şekilde metabolize edilirler (8). İnorganik demir minerali çoğunlukla besinlerde okside ferrik $\left(\mathrm{Fe}^{+3}\right)$ formunda bulunmaktadır. Daha sonra enterosit hücre yüzeyindeki redüktaz görevi gören Duodenal Cytochrıme B (DCYTB) proteini aracılığı ile $\mathrm{Fe}^{+2}$ formuna indirgenmektedir (9). Sonrasında bağırsak hücrelerinin apikal kısmında (besinlerin bağırsağa geldiği yüzey) yer alan demiri transport eden Divalent Metal Transporter 1 proteini (DMT1) sayesinde hücre içerisine alınmaktadır (10). Hücre içerisine alınan demir hücre metabolizması için kullanılabilir, hücre içerisinde depolanabilir veya hücrelerden kana verilerek diğer dokulara gidebilmektedir. Demir kana verilmeden önce ferröz $(\mathrm{Fe}+2)$ formundan $\mathrm{Fe}^{+3}$ formuna dönüşür ve hücrelerin bazolateral (bağırsak hücrelerinin kana bakan yüzey) kısmında bulunan ferroportin (FPN) transport proteini ile kana verilmektedir (11). Ayrıca kandaki demir bazolateral kısımda bulunan Transferrin reseptör proteini (TFR) 
ile enterosit hücrelerine alınmaktadır (12). Demir metabolizmasında rol oynadığı belirtilen genlerin ve proteinlerin sorunsuz çalışmalarıyla beslenme açısından demir eksikliğinin giderilebilmesi mümkün olacaktır.

Hücre içi demir eksikliği enterosit hücrelerinde demir alınımından sorumlu olan genlerin regülasyonunu etkilerken, aynı zamanda demir eksikliğine bağlı hipoksiyanın oluşmasına da neden olmaktadır (13). Demir, hipoksiyada demir metabolizmasında rol oynayan genlerin regülasyonlarını kontrol eden hypoxia inducible 2 alpha (HIF2a) proteinini parçalayan enzimler için kofaktör olarak görev yapar (13,14). Demir eksikliği bu enzimlerin aktivitesini düşürmekte ve HIF2a proteininin parçalanmasını ortadan kaldırarak hücre içerisindeki hipoksik cevabin artmasına neden olmaktadır. İnce bağırsak enterosit hücrelerindeki demirin moleküler mekanizması anlaşılmasına rağmen, bu yolakta görevli genlerin demir eksikliğine bağlı regülasyonlarında diyetsel veya kandaki demirin etkisine ait çalışmalar bulunmamaktadır. Diyetten demiri alıp hücre içine veren transport proteinler apikal kısımda, demiri hücre içerisinden kana veren proteinler ise bazolateral kısımda lokalize olmaktadır. Bağırsak enterosit hücrelerinin apikal ve bazolateral olarak polarize olmaları, bu hücrelerde demir metabolizmasında rol oynayan proteinlerin bulunduğu yer ve görevlerini doğrudan etkilemektedir. Bu da bağırsak hücrelerindeki bu polarizasyonun hücre içi besinlere ait moleküler yolakları farklı şekilde etkileyebileceğine işaret etmektedir. Bu çalışmanın amacı besinlerden alınan ve kanda bulunan demir mineralinin demir eksikliği ile oluşan anemide bağırsak demir metabolizmasının moleküler ve genetik düzenlenmesinde etkisinin incelenmesidir.

\section{GEREÇ VE YÖNTEM}

\section{Hücre Hattı}

Enterosit hücrelerinin doğrudan bağırsak dokusundan alınarak kısa bir zaman diliminde laboratuvar ortamında kullanılmasının zorluğundan dolayl, kültüre edilebilen ve uygun koşullar içinde metabolik olarak aktif olan alternatif hücre modellerinin oluşturulması önemlidir. Yapılan çalışmalar sonucunda, insan kolon karsinoma hücrelerinin (Caco-2) yaklaşık 21 gün boyunca uygun koşullarda kültüre edilmesi durumunda, insan bağırsak enterosit hücresine işlevsel, metabolik ve biyolojik aktivite özellikleri açısından büyük oranda benzerlik gösterdiği saptanmıştır (15-17). Ulaşılabilir hücre modellerine bakıldığında normal insan enterosit hücre modellerine hemen hemen hiç rastlanmamaktadır. Caco-2 hücre hattı besin (18), ilaç (19) ve işlevsel maddelerin etkileri ile ilgili çalışmalarda (20), enterosit demir ve bakır metabolizmalarında sıklıkla kullanılan en yaygın besi yeri olacak şekilde hücre modelidir (21-25). Bu çalışmada kullanılan Caco-2 hücreleri için \%20 sığır serumu, \%1 penisilin-streptomisin, \%1 elzem olmayan aminoasit karışımı ve \%1 sodyum pirüvat içeren hücre besi yeri (MEM Sigma) besi yeri kullanılmıştır. Hücreler, laboratuvarda $100 \mathrm{~mm}$ çaplı hücre kültürü kaplarında, 1.000.000 hücre/10 mL besi yeri olacak şekilde ve $37^{\circ} \mathrm{C}$ nemli atmosfer altında, $\% 5 \mathrm{CO}_{2}$ içeren hücre kültürü inkübatöründe kültüre edilmiştir.

\section{İnsan Bağırsak Sisteminin Modellenmesi}

İnsan vücudunda bağırsak dokusuna ait besin ögesi emiliminden sorumlu enterosit hücrelerinin en önemli özelliklerinden bir tanesi kutuplaşarak polarize olmalarıdır. Besinlerden gelen besin ögelerini alan transport proteinler hücrenin bir kutbunda, hücre içerisine giren besin ögeleri kana veren transport proteinler ise hücrenin diğer kutbunda lokalize olmuştur. Caco-2 hücre hattını ön plana çlkaran özelliklerden bir tanesi de bu hücrelerin özel membran yüzeylerde ve ideal koşullarda 21 gün süre ile büyütüldüklerinde polarize olmalarıdır. Polarize olan hücreler, insan ince bağırsak sisteminde olduğu gibi apikal (besinlerin mideden gelerek bağırsak ile ilk temas ettiği lümen kısmı) ve bazolateral (besin ögelerinin emildikten sonra kana verildiği, vücut içine açılan kan damarları ile 
temas ettiği kısım) bölgeler olarak özelleşmektedirler (17). Bu özelliklerinden dolayı in vivo koşullar için hedeflenen ince bağırsak besin ögelerinin emilim ve metabolizma çalışmaları öncesinde en yaygın kullanılan in vitro sistemdir. Deneysel hücre hattı hazırlanırken kullanılan malzemeler ve yöntem Şekil 1'de gösterilmiştir. Hücrenin büyütüldüğü sistem, hücrelerin tutunmasına yardımcı kollajen proteini ile kaplı 0.4 mikron büyüklüğünde porları olan, 12 mm çapında politetrafluoroetilen malzemesinden oluşan bir membran ve bu membranın yerleştiği bir hücre kültür kabından meydana gelmektedir. Deneysel hücreler hazırlanırken, ilk olarak her bir membran üzerine 10.000 Caco-2 hücresi konulmuştur. Membranın üst kismına $500 \mu \mathrm{L}$ alt kısmına ise $1.5 \mathrm{~mL}$ besi yeri eklenmesi sonrasında hücrelerin büyümeleri mikroskopta düzenli olarak kontrol edilmiştir. Hücrelerin membranın tüm yüzeyini kaplaması için gerekli süre yaklaşık üç gündür. Farklılaşmaları için toplam yirmi bir gün boyunca hücreler bu ortamda her iki günde bir besi yerleri yeni besi yeri ile değiştirilerek inkübe edilmiştir. Bu model tam olarak insan ince bağırsak sistemini taklit ederek, araştırılan olası aktif moleküllerin transportunda en yaygın olarak kullanılan hücre modelidir $(16,26,27)$. $\mathrm{Bu}$ sistemde üst taraf apikal, alt taraf ise bazolateral kısım olarak tanımlanmaktadır.

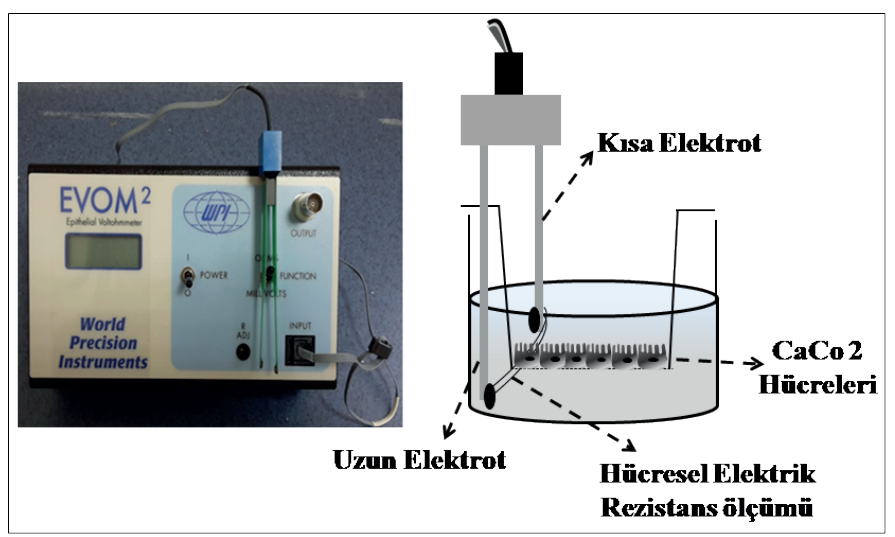

Şekil 1. Hücre büyütülmesinde kullanılan sistem

Hücre bariyer sisteminin tam olarak istenilen düzeyde olup olmadığının takibi çok önemlidir. Hücrelerin tek bir sıra halinde boşluksuz bir yapı ve şekilde olup olmadığı, hemen hemen birçok çalışmada kullanılan hücre epitelyal elektriksel bariyer direncine bakılarak karar verilmiştir (17). Bu ölçümü yapan cihaz, farklı uzunlukta iki ucu olan bir elektrota sahiptir. Bu elektrotun uzun olan ucu, hücrelerin bazolateral kısmının baktığı tarafa, kısa ucu ise apikal kısmının baktığı tarafa yerleştirilerek hücrelerin oluşturduğu epitelyal elektriksel bariyer direncine ohm cinsinden cihaz tarafından ölçülmüştür (Şekil 2). Bu değerin Caco-2 hücreleri için en az $250 \mathrm{ohm} / \mathrm{cm}^{2}$ olduğu belirlenmiş olup, bu değere hücre inkübasyonunun ortalama olarak 4. gününden itibaren ulaşıldığı (28) ve hücre epitelyal elektriksel bariyer direnç değerinin 21-25. günlerde yaklaşık 900-1200 ohm/ $\mathrm{cm}^{2}$ ye kadar çıktığı gözlenmiştir (29).

\section{Demir Eksikliğine Bağlı Aneminin Oluşturulması ve Hücrelere Demir Mineralinin Uygulanması}

Demir eksikliğine bağlı anemi, demiri bağlayan bir kimyasal ajan olan Deferoksamin (DFO) kullanılarak oluşturulmuştur. Deferoksamin, demir metabolizmasında anemik koşulun oluşturulması için kullanılan çok yaygın bir moleküldür $(13,30)$. Deferoksamin, ortamdaki demiri hücre için kullanılamayacak forma getirir ve hücreler bu oluşturulan ortamda demir minerali yokmuş gibi anemi fenotipi göstermektedirler. Yirmi bir gün boyunca hücre kültürü kaplarında büyütülen hücrelerin besi yerlerine $200 \mu \mathrm{M}$ DFO eklenerek yirmi dört saat süreyle inkübe edilmiş ve demir eksikliği şartları oluşturulmuştur. Yirmi dördüncü saatten itibaren ortama ferrik amonyum sitrat (FAC) formunda $100 \mu \mathrm{g} / \mathrm{mL}$ demir verilmiştir. Demir olarak FAC formunun seçilmesinin nedeni bu formun fizyolojik şartlara uygun olması ve daha önceki çalışmalarda kullanılmasıdır (13). 


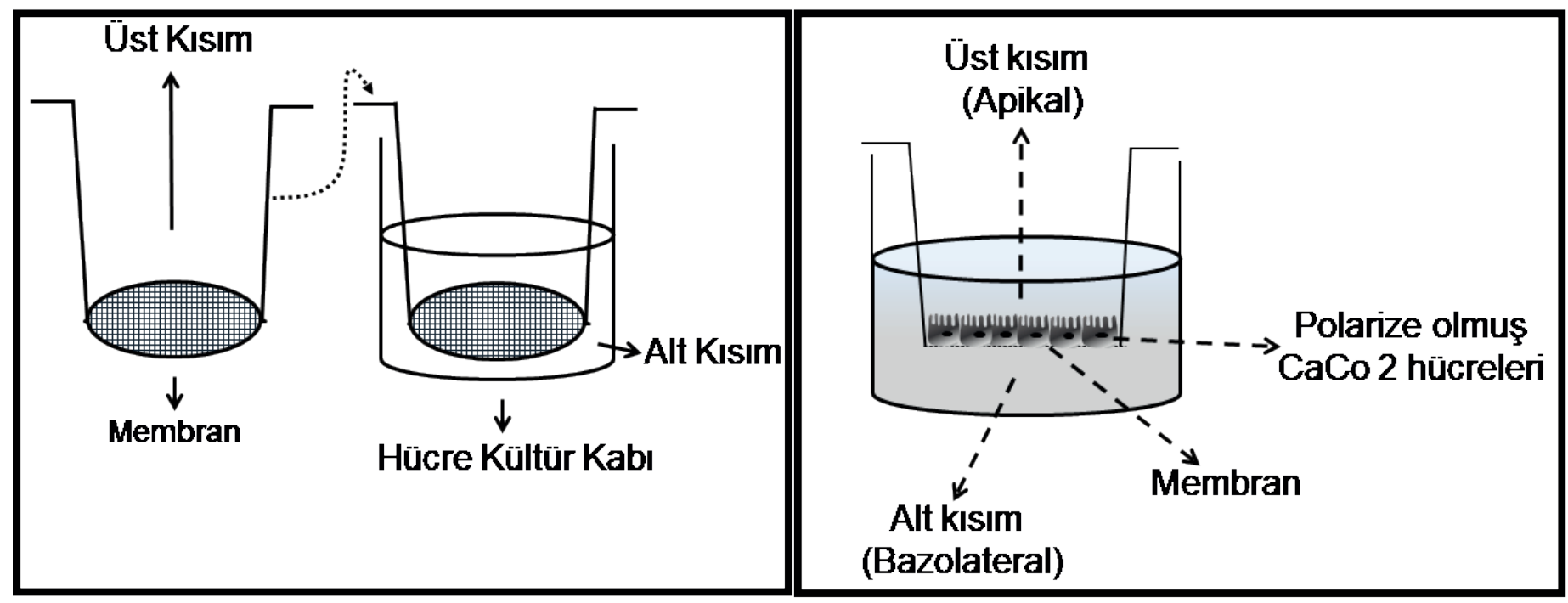

Şekil 2. Hücre elektriksel bariyer direnci (TEER) ölçümü

\section{Genetik Analizler}

Demir mineral muamelesi sonrasında hücrelerden RNA izolasyonu ve tamamlayıcı DNA (cDNA) sentezini takiben gerçek zamanlı polimeraz zincir reaksiyonu (RT-qPCR) yöntemi ile deneysel gruplar arasındaki mesajcı RNA (mRNA) düzeylerindeki farklılıklar hesaplanmıştır. RNA izolasyonu, RNAzol kimyasalı kullanılarak ve firma protokolü (MRC. Inc.) izlenerek yapılmıştır. cDNA reaksiyonu, izole edilmiş tek iplik RNA fragmentlerinin tamamlayıcı zincirinin sentez işlemi olarak tanımlanabilir. Bu teknikle RNA örnekleri, poly-A nükleotidi ve küçük altı bazlık nükleotit primerleri içeren cDNA sentez solüsyonu (enzim ve gerekli kofaktörleri içermektedir) ile uygun sıcaklık değişimlerine bağlı olarak sentezlenmiştir. Daha sonra çalışmada kullanılan ekspresyon düzeyine bakmak için, mRNA sekans dizisine özgü primerler tasarlanmıştır (Tablo 1). Deneysel gruplar arasındaki mRNA gen ekspresyon düzeyleri “SYBR Green” yöntemi ile qPCR cihazı kullanılarak belirlenmiştir. Cihazın mRNA fragmentinden gelen floresan sinyali gördüğü anda verdiği sayısal değer (Ct) değerleri her bir örnek için alınmış ve daha sonra $2^{-\Delta \Delta C t}$ analiz yöntemine göre hesaplanıp örneklerdeki mRNA düzeyleri karşllaştırılmıştır (31). Bu çalışmada normalizasyon için cyclophilin gen mRNA'sı kullanılmıştır.

Tablo 1. Genlere ait mRNA düzeylerinin belirlenmesinde kullanılan primer baz dizileri

\begin{tabular}{lll}
\hline Gen sembolü & İeri yöndeki sekans dizisi & Geri yöndeki sekans dizisi \\
\hline DMT1 & TGCATCTTGCTGAAGTATGTCACC & CTCCACCATCAGCCACAGGAT \\
FTN & CCAGAACTACCACCAGGACTCA & GTTCTTCAAAGCCACATCATCG \\
FPN & GCAGGAGAAGACAGAAGCAAACT & TCCTTCGAATTGTGGCATTCAT \\
TFR & TCAGAGCGTCGGGATGATATCGG & CTTGATCCATCATCATTCTGAACTGCC \\
ANKRD37 & AGCAGTCGCCTGTCCACTTAGC & AGCAGGCTTAGGCACTCCAGG \\
EGLN3 & GCAAATACTACGTCAAGGAGAGGTCTAA & GGCATCCCAATTCTTGTTCAGATAG \\
CYPA & TACGGGTCCTGGCATCTTG & CGAGTTGTCCACAGTCAGCA
\end{tabular}




\section{İstatistiksel Analiz}

Çalışma kapsamında yapılan analizler, birbirinden bağımsız olarak en az üç deney ve her bir deneyde de en az üç deneysel tekrar olacak şekilde yapılmıştır. Projeye aittüm analizlerinhazırlanmasında, GraphPad Prism (versiyon 5.0) programı kullanılmıştır. İki gruba ait örneklerin karşılaştırılmasında, Student's t-testi yöntemi kullanılarak karşılaştırılmıştır. İki veya daha fazla grup birbiri ile karşılaştırılırken "Tek Yönlü Varyans Analizi (One-Way ANOVA)” testi ve “Tukey” yardımcı testi kullanılmıştır. Grafik sonuçları ortalama $(\overline{\mathrm{X}}) \pm$ standart sapma (S) olarak verilmiştir. Gruplar arasında anlamlı farklılık $\mathrm{p}<0.05$ olarak belirlenmiştir.

\section{BULGULAR}

\section{Deneysel Gruplarda Hücre Bariyer Direncinin Ölçülmesi}

İnsan ince bağırsak sisteminin en önemli özelliği enterosit hücrelerine ait apikal ve bazolateral polarizasyona bağlı olarak vücut için bir geçit sistemi oluşturmasıdır. Bu sisteminin fizyolojik olarak düzenli çalışmasında hücreler arası geçirgenliğin kontrolü önemlidir. Bu kontrol moleküler ve genetik düzeyde sağlanmaktadır. Hücreler oluşturduğu polarizasyona bağlı olarak hücre epitelyal elektriksel bariyer direnç oluşturmaktadırlar. Bu çalışmada, demir eksikliğine bağlı aneminin oluşturulması için verilen DFO'nun ve sonrasinda uygulanan demir muamelesinin hücre bariyer direncine etkileri araştırılmıştır. Yirmi bir gün süre ile membran sisteminde büyüyen hücrelerin büyüme ortamına ayrı ayrı veya beraber verilen DFO ve demir (Fe) grupları kontrol grupları ile kıyaslandığında anlamlı bir değişim gözlenmemiştir ( $p>0.05)$. Ayrıca deneysel gruplardan ölçülen TEER değerlerinin $1000 \Omega / \mathrm{cm}^{2}$ nin üzerinde $\left(>250 \Omega / \mathrm{cm}^{2}\right)$ olduğu gözlenmiştir (Şekil 3).

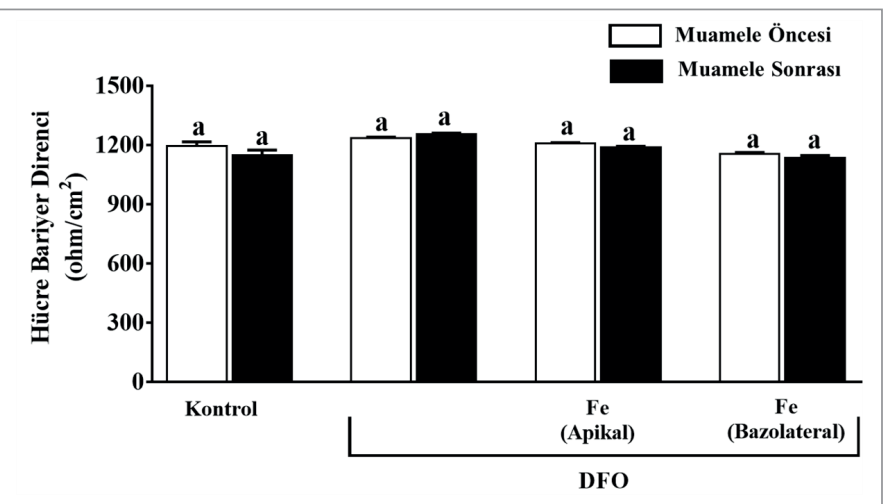

Şekil 3. Hücre bariyer direncinin ölçümü. Hücreler yirmi bir gün boyunca özel membran üzerinde büyütülerek polarize olmaları sağlanmıştır. Deneysel muamelelerin hücre polarizasyonuna etkisi hücre bariyer direncinin ölçümü ile belirlenmiştir. Tüm gruplar için $p \geq 0.05$ olarak bulunmuştur.

Hücrelerin Apikal ve Bazolateral Kısımlarına Verilen Demirin Anemi ve Hipoksiya Üzerindeki Etkisinin Genetik Düzeyde Belirlenmesi

Özel membran sisteminde apikal ve bazolateral olarak polarize olan hücrelere DFO verilerek demir eksikliğine bağlı anemi oluşturulmuştur. Deferoksaminin etkisi demir metabolizmasında rol oynayan ve demir eksikliğine bağlı olarak etkilenen TFR ve DMT1 gen mRNA düzeylerine bakllarak test edilmiştir (Şekil 4A). Her bir gen kendi grubundaki kontrol ile karşılaştırılmış olup, hücrelere sadece DFO verildiğinde $T F R$ ve $D M T 1$ mRNA düzeylerinin anlamlı derecede arttığı görülmüştür (TFR için: $\mathrm{p}<0.001$, DMT1 için: $\mathrm{p}<0.01)$. Ayrıca, demir eksikliğine bağlı olarak anemi oluşturulmuş hücrelerin sadece apikal veya sadece bazolateral kısımlarına demir verilip TFR ve DMT1 mRNA düzeylerine bakılmıştır. Sadece bazolateral kısma demir verildiğinde, TFR ve DMT1 mRNA ekspresyon düzeylerinin sadece apikal kısma verilene kıyasla anlamlı bir şekilde azaldığ bulunmuştur (TFR için: $\mathrm{p}<0.001, D M T 1$ için: $\mathrm{p}<0.001$ ) (Şekil 4A). İnce bağırsakta demirin kana verilmesinden tek sorumlu olan FPN proteinini 
kodlayan mRNA düzeyi DFO ve demire bağlı bir regülasyon göstermemiştir. Bunun yanı sıra, DFO ve bazolateral demir (G4) muamelesine bağlı olarak FPN mRNA düzeyi, DFO ve apikal kısma verilen demir muamelesinde (G3) gözlenen sonuca göre anlamlı derece azalmıştır $(\mathrm{p}<0.05)$. Hücre içi demir depolanmasindan sorumlu olan Ferritin (FTN) mRNA düzeyi de DFO ve demir muamelerine bağlı olarak bir değişim göstermemiştir (Şekil 4A).

Hipoksiya, ince bağırsak demir emiliminden sorumlu yakın zamanda tanımlanan en önemli hücresel sinyal mekanizmasıdır. Bu çalışma kapsamında hipoksiyaya bağlı olarak düzeyi arttığı bilinen ankyrin repeat domain 37 (ANKRD37) ve egln-9 homolog 3 (EGLN3) genleri belirteç olarak kullanılmıştır. Hücrelere DFO verildiğinde (G2) ANKRD37 ve EGLN3 mRNA düzeyleri kontrol grubuna göre (G1) anlamlı derecede artmıştır (ANKRD37 için p<0.001, EGLN3 için p<0.01). Bu mRNA'lardaki artış bazolateral demir verilen grup ile apikal kısma demir verilen grup kıyaslandığında anlamlı derecede azalmaktadır (ANKRD37 için $\mathrm{p}<0.001$, EGLN3 için p<0.05) (Şekil 4B).
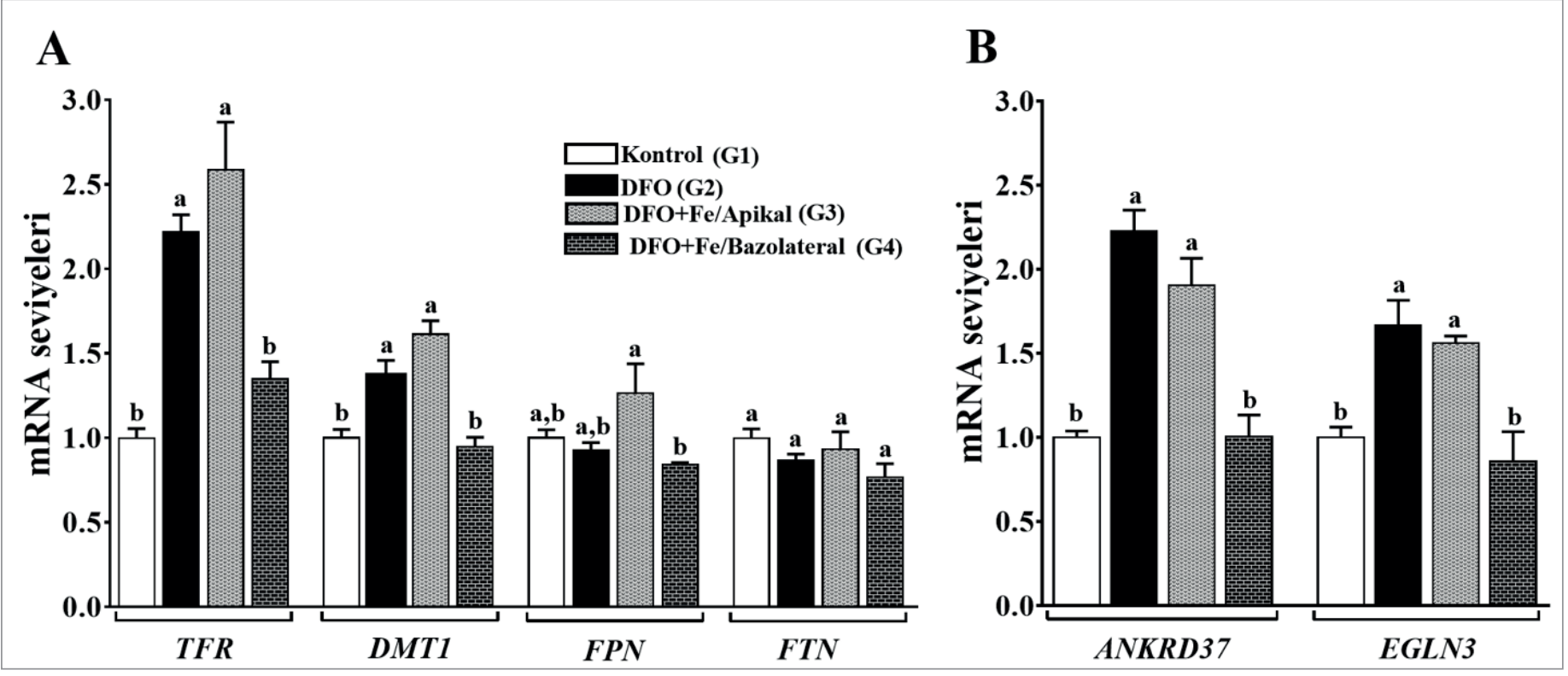

Şekil 4A ve 4B. Demir mineralinin anemi durumunda ince bağırsak demir ve hipoksiya metabolizmasında rol oynayan genlerin ekspresyonlarına etkisi. Hücreler 21 gün boyunca membran sisteminde büyütülerek polarize olmaları sağlanmıştır. Hücrelere DFO muamelesi sonrasında apikal ve bazolateral kısımlara demir minerali verilmiştir. (G1: her hangi bir muamele yapılmamış grup, G2: DFO ile anemi oluşturulan grup, G3: DFO ile anemi oluşturulmuş ve sadece apikal kısma demir muamelesi yapılmış grup, G4: DFO ile anemi oluşturulmuş ve sadece bazolateral kısma demir muamelesi yapılmış grup). Örneklerden RNA izolasyonu yapılmış ve cDNA sentezi sonrasında RT-qPCR yöntemi ile gen ekspresyon düzeyleri belirlenmiştir. Sonuçlar Cyclophilin A (CypA) mRNA’sına göre normalize edilmiştir. Her bir gene ait sonuclar kendi içerisinde birbirleri ile karşılaştırılmıştır. Gruplar arasındaki farklılık tek yönlü varyans analizi (ANAVO) ve Tukey’s post-hoc testi ile hesaplanmış ve $\mathrm{p} \leq 0,05$ olan gruplar anlamlı olarak kabul edilmiştir. Deneylerde kullanılan örnek sayısı: n:3/grup ve deneyler 3 farklı bağımsız tekrarlı olarak yapılmıştır. Sonuçlar ortalama $(\overline{\mathrm{X}}) \pm$ standart sapma (S) olarak verilmiştir. DFO: Deferoksamin, TFR: Transferrin Receptor, DMT1: Divalent metal transporter 1, FPN: Ferroportin, , FTN: Ferritin, ANKRD37: Ankryin Repeat Domain 37, EGLN: Hif prolyl hydroxylase 3. 


\section{TARTIŞMA}

$\mathrm{Bu}$ çalışma kapsamında ilk defa diyetten gelen ve kandaki demir mineralinin anemik durumda ince bağırsak demir metabolizmasındaki etkisi gösterilmiştir. Bu çalışmayı özgün kllan en önemli noktalardan bir tanesi, insan ince bağırsak sisteminin modellenerek diyetten gelen ve kandaki demir mineralinin etkisinin ayrı ayrı çalışılmasıdır. İnsan ince bağırsak hücreleri, vücut içi ve dışı arasında belirli bir düzende sıralanıp bir araya gelerek besin ögeleri için kontrollü bir geçiş sağlarken, yabancı moleküllerin geçişine de izin vermemektedirler. Besin ögeleri, enterosit hücrelerinin bağırsak lümenine bakan kısmından (apikal kısım) hücre içerisine alınır ve vücut içerisine bakan kısmından da (bazolateral kısım) kana verilir. Bu özelliklerinden dolayı bu hücreler kutuplaşmış (polarize) bir yapıya sahiptirler. İnce bağırsak dokusunun yapısı bu çalışma kapsamında in vitro olarak modellenmiştir. İnsan ve hayvan çalışmalarında sistemik etkilerin olması (örneğin, karaciğer dokusunda salgılanan bir proteinin ince bağırsak dokusundaki besin ögesine ait metabolizmayl etkilemeleri) ve dokuların bir bütün halinde sistemli çalışmaları tek bir dokudaki besin ögelerine ait metabolizmaların doku bazında etkilerinin çalışılmasını zorlaştırmaktadır. $\mathrm{Bu}$ yönü ile de bu çalışmada kullanılan hücre modeli ve hücrelerin büyütülme şekli diyetten gelen ve kandaki besinsel etmenlerin çalışılmasına olanak sağlamıştır. Bu çalışmada kullanılan deneysel model kanser hücresi olmasına rağmen, özel membran sistemlerinde büyütülüp yirmi bir gün sonra farklılaşarak polarize olmaktadır ve böylece insan bağırsak sistemini fizyolojik olarak modelleyebilmemize olanak sağlamaktadır. $\mathrm{Bu}$ hücre sistemi besin desteklerinin geliştirilmesinde $(32,33)$, ilaç emilim çalışmalarında (19), ince bağırsak mineral fizyolojisini içeren çalışmalarda (21-23) en çok tercih edilen hücre modelidir. Bunun yanında, insan bağırsak sisteminin modellendiği kanser olmayan hücre hattının bulunmamasından dolayı da bu çalışmada kullanılmak üzere Caco-2 hücre hattı seçilmiştir.
Memelilerde demirin vücuttan atılmasını sağlayan özelleşmiş bir sistem bulunmamaktadır (8). İnce bağırsak enterosit hücreleri vücut içerisinde demir miktarının belirli bir düzeyde tutularak vücut içi demir homeostazının kontrol edilmesini sağlamaktadırlar (8). Bağırsaktan demir emiliminin etkin bir şekilde olması, demir eksikliğine bağlı aneminin önlenmesinde gerekli fizyolojik bir olaydır. $\mathrm{Bu}$ yüzden anemik durumda bağırsak enterosit hücrelerindeki demir metabolizmasının kontrolünün anlaşılması önemlidir. Enterosit hücreleri ince bağırsak dokusunda hem besinlerden gelen besin ögeleri hem de vücut dolaşımındaki kan ile aynı anda temas halindedir. Bu özelliğinden dolayı besinlerden gelen demiri hücre içerisine alan proteinler bir kutupta, demiri kana veren protein ise diğer kutupta bulunmaktadır. Bu çalışmada demir eksikliğine bağlı anemide besinlerden gelen ve kanda bulunan demirin enterosit hücrelerindeki etkisi demir metabolizmasinda rol oynayan TFR, DMT1 ve $F P N$ genlerinden sentezlenen mRNA düzeylerine bakılarak araştırılmıştır. TFR ve DMT1 genlerine ait mRNA düzeyinin demir eksikliğine bağlı olarak enterosit hücrelerinde arttığ in vivo ve in vitro deney modellerinde gösterilmiştir $(34,35)$. Bu çalışmada da, bu genlerin mRNA düzeylerinin demir eksikliği oluşturmak için kullanılan ve hücre besi yerindeki demiri bağlayan deferoksamin (DFO) ile muamele edilmiş hücrelerde arttığı bulunmuştur.

Hücrelerdeki anemik durum demir verildiğinde ortadan kalkmaktadır. Ancak enterosit hücrelerinde aneminin etkisinin ortadan kalkmasında bazolateral kısma verilen demirin apikal bölgeye verilen demire göre daha baskın olarak demir metabolizmasında görevli genlerin mRNA düzeylerine etki ettiği ve DFO ile artan TFR ve DMT1 mRNA düzeylerini azaltığ gösterilmiştir. Bu sonuç kandaki demirin enterosit hücre demir metabolizmasınin kontrolünde daha önemli olduğuna işaret etmektedir. FPN mRNA düzeyi özellikle hücre içi demir miktarına bağlı olarak kontrol edilirken, hücre düzeyinde anemik 
durumda regüle olmamaktadır $(34,36)$. Bu çalışmada, DFO tek başına verildiğinde, FPN mRNA düzeyine etki etmezken, bazolateral kısma verilen demirin $F P N$ mRNA düzeyini azalttığı gösterilmiştir.

Çalışmada demir eksikliğine bağlı oluşan hipoksiyadan etkilenen ANKRD37 ve EGLN3 genlerinin mRNA düzeyleri de incelenmiştir. $\mathrm{Bu}$ genlerin mRNA düzeyleri demirin hipoksiya üzerindeki etkisinin gösterilmesi adına belirteç olarak kullanılmıştır. Deferoksamin verilen gruplarda ANKRD37 ve EGLN3 mRNA düzeylerinin arttığı bulunmuştur. Bu artış DFO'nun neden olduğu hipoksik ortamın oluştuğunu göstermektedir. Bu genlerin mRNA düzeylerindeki artış sadece bazoletaral kısma verilen demir ile azalmaktadır (Şekil 4B). Sonuçlar hücre içerisindeki hipoksik durumun ortadan kalkmasında kandaki demir mineralinin besinlerden gelen demire göre daha etkili olduğunu işaret etmek etmektedir.

Kandaki demir düzeyinin, demir eksikliğine bağlı oluşan anemik durumda ince bağırsak demir metabolizmasında etkin bir role sahip olduğu bu çalışmada gösterilmiştir. Ancak en önemli noktalardan bir tanesi kandaki demir oranının kontrolüdür. Bu yüzden besin ögelerinin alınan miktarı kadar bağırsaktan verimli bir şekilde emilip kana geçen miktarı da önemlidir. $\mathrm{Bu}$ bağlamda, günlük demir içeren besinlerin yeterli miktarda tüketiminin öneminin yanında, besinlerin içerisindeki demirin ince bağırsak enterosit hücrelerinden emiliminin (biyoyararlanımının) de önemli olduğu unutulmamalıdır. Bu nedenle demir içeren besinlerin tüketimindeki önerilerde demirin ince bağırsaktan emilimini etkileyen etmenler göz önünde bulundurulmalıdır. Ayrıca çalışmadan çıkan sonuçlarla enterosit hücrelerindeki demir metabolizmasına bağlı moleküler yolakların hücrelerin kana bakan kısımlarından (bazolateral) etkilendiği ortaya konmuştur. İleriki çalışmalarda demir mineralinin hücreler tarafından algılanma mekanizmasının bulunması demir hastalıkları (anemi veya hemokromatoz) gibi durumlarda demir emiliminin kontrolü adına önemli olacaktır.
Demir mineraline ait insan vücudundaki moleküler mekanizmaların anlaşılması anemi durumdaki demir desteklerinin kullanımları ve hedef gruplardaki etkilerinin daha iyi olması adına önemli olacaktır. Bunun yanında çalışmada kullanılan hücreler ile insan ince bağırsak sisteminin modellenmesi laboratuvar koşullarında besin ögelerinin biyoyararlanımlarının çalışılması ve ince bağırsaktaki besin ögelerinin metabolizmalarının anlaşılmasına olanak sağlayan bir yaklaşımdır.

Çıkar çatışması - Conflict of interest: Yazarlar çıkar çatışması olmadığını beyan ederler. - The authors declare that they have no conflict of interest.

Maddi destek - Funding source: Bu çalışma TÜBİTAK (Proje No:215Z041) tarafindan desteklenmiştir. - This study was supported by TÜBITAK (Project Number:215Z041)

\section{KAYNAKLAR}

1. Zimmermann MB, Hurrell RF. Nutritional iron deficiency. Lancet 2007;370(9586):511-520.

2. DeLoughery TG. Iron deficiency anemia. Med Clin North Am 2017;101(2):319-332.

3. Miller JL. Iron deficiency anemia: a common and curable disease. Cold Spring Harb Perspect Med 2013;3(7),pii: a011866. doi: 10.1101/cshperspect.a011866.

4. World, Health, Organization. Archived: Iron deficiency anaemia: assessment, prevention and control. A guide for proramme managers. In: Organization $\mathrm{WH}$, ed. Geneva:, 2001. Available at http://www.who.int/ nutrition/publications/micronutrients/anaemia_iron_ deficiency/WHO_NHD_01.3/en/. Access July 24, 2018.

5. Republic of Turkey State Planning Organization of the National Food and Nutrition Strategy Working Group Report. Yayın No DPT: 2670 Turkey, 2003. Available at http://tarim.kalkinma.gov.tr/wpcontent/ uploads/2015/01/ Ulusal_GidaveBeslenme_Eylem_ PlaniTaslak-04-11-2014.pdf. Access July 24, 2018:43.

6. Knutson M, Wessling-Resnick M. Iron metabolism in the reticuloendothelial system. Crit Rev Biochem Mol Biol 2003;38(1):61-88.

7. Theil EC. Iron homeostasis and nutritional iron deficiency. J Nutr 2011;141(4):724S-728S.

8. Gulec S, Anderson GJ, Collins JF. Mechanistic and regulatory aspects of intestinal iron absorption. Am J Physiol Gastrointest Liver Physiol 2014;307(4):G397-409. 
9. Lane DJ, Bae DH, Merlot AM, Sahni S, Richardson DR. Duodenal cytochrome b (DCYTB) in iron metabolism: an update on function and regulation. Nutrients 2015;7(4):2274-2296.

10. Conrad ME, Umbreit JN. Iron absorption and transportan update. Am J Hematol 2000;64(4):287-298.

11. Drakesmith $H$, Nemeth E, Ganz T. Ironing out Ferroportin. Cell Metab 2015;22(5):777-787.

12. Shah D, Shen WC. The establishment of polarity and enhanced transcytosis of transferrin receptors in enterocyte-like Caco-2 cells. J Drug Target 1994;2(2):9399.

13. Hu Z, Gulec S, Collins JF. Cross-species comparison of genomewide gene expression profiles reveals induction of hypoxia-inducible factor-responsive genes in irondeprived intestinal epithelial cells. Am J Physiol Cell Physiol 2010;299(5):C930-938.

14. Shah YM, Matsubara T, Ito S, Yim SH, Gonzalez FJ. Intestinal hypoxia-inducible transcription factors are essential for iron absorption following iron deficiency. Cell Metab 2009;9(2):152-164.

15. Sambuy Y, De Angelis I, Ranaldi G, Scarino ML, Stammati A, Zucco F. The Caco-2 cell line as a model of the intestinal barrier: influence of cell and culture-related factors on Caco-2 cell functional characteristics. Cell Biol Toxicol 2005;21(1):1-26.

16. Delie F, Rubas W. A human colonic cell line sharing similarities with enterocytes as a model to examine oral absorption: advantages and limitations of the Caco-2 model. Crit Rev Ther Drug Carrier Syst 1997;14(3):221286.

17. Hidalgo IJ, Raub TJ, Borchardt RT. Characterization of the human colon carcinoma cell line (Caco-2) as a model system for intestinal epithelial permeability. Gastroenterology 1989;96(3):736-749.

18. Yin L, Vijaygopal P, MacGregor GG, Menon R, Ranganathan P, Prabhakaran S, et al. Glucose stimulates calcium-activated chloride secretion in small intestinal cells. Am J Physiol Cell Physiol 2014;306(7):C687-696.

19. Wilson G. Cell culture techniques for the study of drug transport. Eur J Drug Metab Pharmacokinet 1990;15(2):159-163.

20. Satake M, Enjoh M, Nakamura Y, Takano T, Kawamura Y, Arai S, et al. Transepithelial transport of the bioactive tripeptide, Val-Pro-Pro, in human intestinal Caco-2 cell monolayers. Biosci Biotechnol Biochem 2002;66(2):378384.

21. Han O, Wessling-Resnick M. Copper repletion enhances apical iron uptake and transepithelial iron transport by Caco-2 cells. Am J Physiol Gastrointest Liver Physiol 2002;282(3):G527-333.
22. Linder MC, Zerounian NR, Moriya M, Malpe R. Iron and copper homeostasis and intestinal absorption using the Caco2 cell model. Biometals 2003;16(1):145-160.

23. Chicault C, Toutain B, Monnier A, Aubry M, Fergelot P, Le Treut A, et al. Iron-related transcriptomic variations in CaCo-2 cells, an in vitro model of intestinal absorptive cells. Physiol Genomics 2006;26(1):55-67.

24. Zhu L, Glahn RP, Yeung CK, Miller DD. Iron uptake by Caco-2 cells from NaFeEDTA and FeSO4: Effects of ascorbic acid, pH, and a Fe(II) chelating agent. J Agric Food Chem 2006;54(20):7924-7928.

25. Pourvali K, Matak P, Latunde-Dada GO, Solomou S, Mastrogiannaki M, Peyssonnaux C, et al. Basal expression of copper transporter 1 in intestinal epithelial cells is regulated by hypoxia-inducible factor 2alpha. FEBS Lett 2012;586(16):2423-2427.

26. Meunier V, Bourrie M, Berger Y, Fabre G. The human intestinal epithelial cell line Caco-2; pharmacological and pharmacokinetic applications. Cell Biol Toxicol 1995;11(3-4):187-194.

27. Failla ML, Huo T, Thakkar SK. In vitro screening of relative bioaccessibility of carotenoids from foods. Asia Pac J Clin Nutr 2008;17 Suppl 1:200-203.

28. Liang E, Chessic K, Yazdanian M. Evaluation of an accelerated Caco-2 cell permeability model. J Pharm Sci 2000;89(3):336-345.

29. Louvard D, Kedinger M, Hauri HP. The differentiating intestinal epithelial cell: establishment and maintenance of functions through interactions between cellular structures. Annu Rev Cell Biol 1992;8:157-195.

30. Zerounian NR, Linder MC. Effects of copper and ceruloplasmin on iron transport in the Caco 2 cell intestinal model. J Nutr Biochem 2002;13(3):138-148.

31. Gulec S, Collins JF. Silencing of the Menkes coppertransporting ATPase (Atp7a) gene increases cyclin D1 protein expression and impairs proliferation of rat intestinal epithelial (IEC-6) cells. J Trace Elem Med Biol 2014;28(4):459-464.

32. Glahn RP, Lai C, Hsu J, Thompson JF, Guo M, Van Campen DR. Decreased citrate improves iron availability from infant formula: application of an in vitro digestion/ Caco-2 cell culture model. J Nutr 1998;128(2):257-264.

33. Wortley G, Leusner S, Good C, Gugger E, Glahn R. Iron availability of a fortified processed wheat cereal: a comparison of fourteen iron forms using an in vitro digestion/human colonic adenocarcinoma (CaCo-2) cell model. Br J Nutr 2005;93(1):65-71.

34. Gulec S, Collins JF. Silencing the Menkes coppertransporting ATPase (Atp7a) gene in rat intestinal epithelial (IEC-6) cells increases iron flux via transcriptional induction of ferroportin 1 (Fpn1). J Nutr 
2014;144(1):12-19.

35. Collins JF. Gene chip analyses reveal differential genetic responses to iron deficiency in rat duodenum and jejunum. Biol Res 2006;39(1):25-37.
36. Aydemir F, Jenkitkasemwong S, Gulec S, Knutson MD. Iron loading increases ferroportin heterogeneous nuclear RNA and mRNA levels in murine J774 macrophages. J Nutr 2009;139(3):434-438. 